\title{
Impact of detection bias on the risk of gastrointestinal cancer and its subsites in type 2 diabetes mellitus
}

Citation for published version (APA):

de Jong, R. G. P. J., Burden, A. M., de Kort, S., van Herk-Sukel, M. P. P., Vissers, P. A. J., Janssen, P. K. C., Haak, H. R., Masclee, A. A. M., de Vries, F., \& Janssen-Heijnen, M. L. G. (2017). Impact of detection bias on the risk of gastrointestinal cancer and its subsites in type 2 diabetes mellitus. European Journal of Cancer, 79, 61-71. https://doi.org/10.1016/j.ejca.2017.03.039

Document status and date:

Published: 01/07/2017

DOI:

10.1016/j.ejca.2017.03.039

Document Version:

Publisher's PDF, also known as Version of record

Document license:

Taverne

Please check the document version of this publication:

- A submitted manuscript is the version of the article upon submission and before peer-review. There can be important differences between the submitted version and the official published version of record.

People interested in the research are advised to contact the author for the final version of the publication, or visit the DOI to the publisher's website.

- The final author version and the galley proof are versions of the publication after peer review.

- The final published version features the final layout of the paper including the volume, issue and page numbers.

Link to publication

\footnotetext{
General rights Owners
rights.

- You may freely distribute the URL identifying the publication in the public portal. please follow below link for the End User Agreement:

www.umlib.nl/taverne-license

Take down policy

If you believe that this document breaches copyright please contact us at:

repository@maastrichtuniversity.nl

providing details and we will investigate your claim.
}

Copyright and moral rights for the publications made accessible in the public portal are retained by the authors and/or other copyright owners and it is a condition of accessing publications that users recognise and abide by the legal requirements associated with these

- Users may download and print one copy of any publication from the public portal for the purpose of private study or research.

- You may not further distribute the material or use it for any profit-making activity or commercial gain

If the publication is distributed under the terms of Article $25 \mathrm{fa}$ of the Dutch Copyright Act, indicated by the "Taverne" license above, 


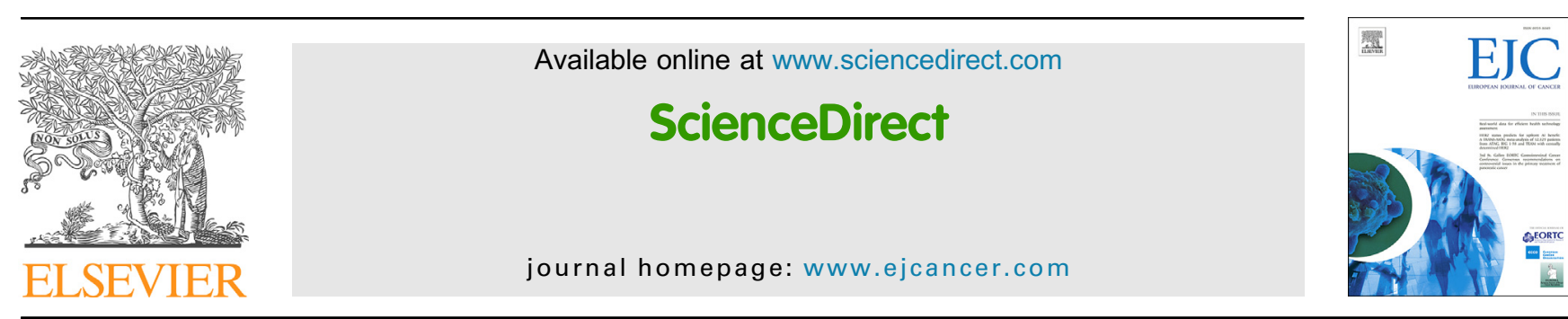

\title{
Original Research
}

\section{Impact of detection bias on the risk of gastrointestinal cancer and its subsites in type 2 diabetes mellitus}

\author{
R.G.P.J. de Jong ${ }^{\mathrm{a}, \mathrm{b}, *}$, A.M. Burden ${ }^{\mathrm{c}, \mathrm{d}}$, S. de Kort ${ }^{\mathrm{e}}$, \\ M.P.P. van Herk-Sukel ${ }^{\mathrm{f}}$, P.A.J. Vissers ${ }^{\text {g }}$, P.K.C. Janssen ${ }^{\mathrm{c}, \mathrm{d}, \mathrm{h}, \mathrm{i}}$, \\ H.R. Haak ${ }^{\mathrm{j}, \mathrm{k}, 1}$, A.A.M. Masclee ${ }^{\mathrm{e}}$, F. de Vries $^{\mathrm{c}, \mathrm{d}, 1, \mathrm{~m}}$, \\ M.L.G. Janssen-Heijnen ${ }^{\text {n,o }}$
}

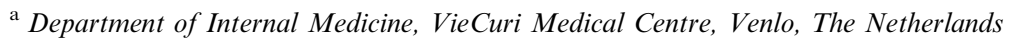

${ }^{\mathrm{b}}$ Department of Internal Medicine, Division of Gastroenterology and Hepatology, GROW-School for Oncology and Developmental Biology, Maastricht University Medical Centre+, Maastricht, The Netherlands

${ }^{\mathrm{c}}$ Department of Clinical Pharmacy and Toxicology, Maastricht University Medical Centre+, Maastricht, The Netherlands

${ }^{\mathrm{d}}$ Utrecht Institute for Pharmaceutical Sciences, Division of Pharmacoepidemiology and Clinical Pharmacology, Utrecht University, Utrecht, The Netherlands

${ }^{\mathrm{e}}$ Department of Internal Medicine, Division of Gastroenterology and Hepatology, NUTRIM - School of Nutrition and Translational Research in Metabolism, Maastricht University Medical Centre+, Maastricht, The Netherlands

${ }^{\mathrm{f}}$ PHARMO Institute for Drug Outcomes Research, Utrecht, The Netherlands

${ }^{g}$ Department of Research, Netherlands Comprehensive Cancer Organization, Utrecht, The Netherlands

${ }^{\mathrm{h}}$ Utrecht Institute for Pharmaceutical Sciences, Division of Pharmacology, Utrecht University, Utrecht, The Netherlands

i Department of Central Hospital Pharmacy, VieCuri Medical Centre, Venlo, The Netherlands

${ }^{j}$ Department of Internal Medicine, Máxima Medical Centre Eindhoven, Eindhoven, The Netherlands

${ }^{\mathrm{k}}$ Department of Internal Medicine, Division of General Internal Medicine, Maastricht University Medical Centre+,

Maastricht, The Netherlands

${ }^{1}$ Department of Health Services Research, CAPHRI School for Public Health and Primary Care, Maastricht University

Medical Centre+, Maastricht, The Netherlands

${ }^{\mathrm{m}}$ MRC Life-course Epidemiology Unit, University of Southampton, Southampton, United Kingdom

${ }^{n}$ Department of Epidemiology, GROW - School for Oncology and Developmental Biology, Maastricht University Medical

Centre+, Maastricht, The Netherlands

${ }^{\circ}$ Department of Clinical Epidemiology, VieCuri Medical Centre, Venlo, The Netherlands

Received 30 December 2016; received in revised form 25 March 2017; accepted 29 March 2017

Available online 29 April 2017

\section{KEYWORDS}

Gastrointestinal cancer;
Abstract Background: Type 2 diabetes mellitus (T2DM) may be a risk factor for gastrointestinal (GI) cancers, but variations in study designs of observational studies may have yielded biased results due to detection bias. Furthermore, differences in risk for GI cancer subsites

\footnotetext{
* Corresponding author: Department of Internal Medicine, VieCuri Medical Centre, PO Box 1926, 5900 BX Venlo, The Netherlands.

E-mail address: roy.dejong@maastrichtuniversity.nl (R.G.P.J. de Jong).
} 
Epidemiology;

Type 2 diabetes mellitus;

Risk factors;

Population based;

Cohort study;

Cancer registry have not been extensively evaluated. We aimed to determine the risk of GI cancer and its subsites in patients with T2DM and how it is affected by detection bias.

Methods: A matched cohort study was performed using the NCR-PHARMO database. Newusers of $\geq 1$ non-insulin anti-diabetic drug during 1998-2011 were matched with non-diabetic controls by year of birth, sex, and time between database entry and index. Cox regression analyses were performed with and without lag-period to estimate hazard ratios (HRs) for GI cancer and its subsites. Covariables included age, sex, use of other drugs and history of hospitalisation.

Results: An increased risk of GI cancer was observed in T2DM patients (HR 1.5, 95\% confidence interval [CI] 1.3-1.7) compared with controls, which was attenuated in the 1-year lagged analysis (HR 1.4, 95\% CI 1.2-1.7). Stratified by subsite, statistically significant increased risks of pancreatic (HR 4.7, 95\% CI 3.1-7.2), extrahepatic bile duct (HR 4.2, 95\% CI 1.5-11.8) and distal colon cancer (HR 1.5, 95\% CI 1.1-2.1) were found, which remained statistically significantly increased in the lagged analysis.

Conclusions: T2DM patients had a 40\% increased risk of GI cancer. Increased GI cancer risks tended to be weaker when reducing detection bias by applying a 1-year lag-period. Future observational studies should therefore include sensitivity analyses in which this bias is minimised.

(c) 2017 Elsevier Ltd. All rights reserved.

\section{Background}

Gastrointestinal (GI) cancers, encompassing malignancies of the gut, from the oesophagus till the anus; including the liver, gallbladder, extrahepatic bile ducts and the pancreas, are among the most common and lethal malignant neoplasms. In 2015 , almost $25 \%$ of the total cancer incidence, and a third of the total cancer mortality in the Netherlands was due to a GI cancer [1]. Furthermore, data from the Netherlands Cancer Registry (NCR) indicate incidences of these cancers are rising [1].

Previous studies using NCR data have shown a higher prevalence of type 2 diabetes mellitus (T2DM) in patients with various GI cancers [2,3]. Indeed, a growing body of evidence suggests that T2DM may be a risk factor for the development of GI cancers (Table 1) [4-13]. The strongest associations have been described for liver and pancreatic cancer, with both a two-fold increased risk [14,15]. In addition, a $15 \%-30 \%$ increased risk has been reported for colorectal cancer [16-18]. With 830,000 individuals living in the Netherlands with diabetes mellitus in 2011 (of which $\pm 90 \%$ with $\mathrm{T} 2 \mathrm{DM}$ ), diabetes mellitus poses a highly prevalent and potentially modifiable risk factor for GI cancer development [19]. There has been much discussion about whether previously reported associations in observational studies present an underlying biological mechanism between T2DM and cancer or represent detection bias or even reverse causality. These biases could have been the result of a diagnostic (protopathic) bias, i.e. an increased odds of detecting cancer shortly after the onset of diabetes, or by specific GI cancers inducing disturbances in glucose homoeostasis [20,21].
To address this form of methodologic bias, a lag time between disease onset and the start of follow-up for cancer outcomes can be considered [22].

Furthermore, epidemiologic studies have shown that risk factors of GI cancer may vary within specific GI cancer anatomic subsites or histologic subtypes [23,24]. For instance, different risk factors have been identified for oesophageal squamous cell carcinoma and adenocarcinoma, and also for proximal and distal gastric cancer [23]. Up to now, data on subsite-specific risks of GI cancer in patients with T2DM are limited [25].

Therefore, our primary aim was to determine the overall risk of GI cancer in patients with T2DM, and explore the effects of detection bias/reverse causality on the association between T2DM and risk of GI cancer. Second, we stratified these analyses for specific GI cancer subsites/subtypes.

\section{Methods}

\subsection{Data source}

Data for this population-based cohort study were obtained from the PHARMO Database Network and linked at the individual patient level to the Eindhoven area of the NCR. The construct and validity of the linked database have been described elsewhere [26]. Data from the Eindhoven area of the NCR, maintained by the Netherlands Comprehensive Cancer Organisation, cover a demographic region with approximately 2.4 million inhabitants ( $\sim 15 \%$ of the Dutch population) and no academic hospitals. Trained registration clerks actively collect data on diagnosis, patient characteristics, staging and initial treatment from hospital medical 
Table 1

Overview of GI cancer risk in patients with type 2 diabetes mellitus in meta-analyses of cohort studies.

\begin{tabular}{|c|c|c|c|c|c|c|}
\hline$\overline{\text { Author (Ref.) }}$ & $\begin{array}{l}\text { Oesophageal } \\
\text { cancer }\end{array}$ & Gastric cancer & Colorectal cancer & Liver cancer & Bile duct cancer & $\begin{array}{l}\text { Pancreatic } \\
\text { cancer }\end{array}$ \\
\hline Larsson et al., 2005 [16] & & & RR $1.30(1.20-1.40)$ & & & \\
\hline Huang et al., 2012 [9] & $\begin{array}{l}\text { SRR } 1.30 \\
(1.12-1.50)\end{array}$ & & & & & \\
\hline Ge et al., $2011[10]$ & & SRR $1.09(0.98-1.22)$ & & & & \\
\hline Ren et al., 2011 [13] & & & & & $\begin{array}{l}\text { GB: SRR } 1.52 \\
(1.26-1.84)\end{array}$ & \\
\hline Ben et al., 2011 [14] & & & & & & $\begin{array}{l}\text { SRR 1.95 } \\
(1.66-2.28)\end{array}$ \\
\hline Jiang et al., 2011 [12] & & & SRR $1.27(1.21-1.34)$ & & & \\
\hline Jing et al., 2012 [11] & & & & $\begin{array}{l}\text { ICC: SRR } 1.97 \\
(1.57-2.46)\end{array}$ & $\begin{array}{l}\text { ECC: SRR } 1.63 \\
(1.29-2.05)\end{array}$ & \\
\hline Wang et al., 2012 [15] & & & & $\begin{array}{l}\text { HCC: SRR } 2.31 \\
(1.87-2.84)\end{array}$ & & \\
\hline Deng et al., 2012 [17] & & & RR $1.26(1.20-1.31)$ & & & \\
\hline Wu et al., 2013 [8] & & & RR $1.22(1.19-1.26)$ & & & \\
\hline
\end{tabular}

Abbreviations: ECC, extrahepatic cholangiocarcinoma; HCC, hepatocellular carcinoma; HR, hazard ratio; GB, gallbladder; ICC, intrahepatic cholangiocarcinoma; Ref, reference number; RR, relative risk; SRR, summary relative risk.

records. Vital status is obtained by linkage to Dutch municipal records.

The PHARMO Database Network is a large, patientcentric data network including linked observational databases designed for drug safety and outcomes research. For this study the Out-patient (community) Pharmacy Database was used, which contains longitudinal drug dispensing records, and included information on dispensing date, dose descriptions and amount dispensed. All drugs are coded according to their Anatomical Therapeutic Chemical/Defined Daily Dose Classification code [27]. Both the NCR and the PHARMO Database Network are recognised as high-quality data sources for (pharmaco-) epidemiological research that have collected information in overlapping regions in the Netherlands for a period of over 10 years [26].

\subsection{Population and study design}

We selected all individuals aged 30 years and older who received at least one anti-diabetic drug (ADD) prescription (ATC code 'A10A' or 'A10B') in the NCRPHARMO database between 1 January 1998 and 31 December 2011. These subjects were classified as potential T2DM patients and the first prescription for an ADD defined their start of follow-up (index date). A random sample of subjects who never received ADDs during the study period was extracted from the database and classified as non-diabetic controls (Fig. 1).

Next, non-diabetic controls were matched to a T2DM patient by year of birth, sex and the time between database entry and the index date ( \pm 90 days). Non-diabetic controls were assigned the same index date as their matched T2DM patients. For T2DM patients with more than one matched control the most optimal control was selected based on highest similarity of matching parameters, yielding a 1:1 matched cohort.
Potential T2DM patients who initiated ADD treatment with insulin or an insulin analogue (ATC code 'A10A') were excluded to minimise the amount of people with type 1 diabetes mellitus being misclassified as T2DM. All study subjects with a history of GI cancer before the index date were excluded. Furthermore, we excluded all prevalent ADD-users, i.e. T2DM patients without a minimum of 1 year of ADD-free follow-up in the NCR-PHARMO database before the index date. In addition, all individuals matched to excluded subjects were excluded as well. Individuals were followed from the index date until the first occurrence of a GI cancer, death from any cause, migration out of the PHARMO catchment area or end of data collection, whichever came first.

\subsection{Outcomes}

GI cancers were classified according to the International Classification of Diseases of oncology [28]. These included 'any GI cancer' (C15-26, excluding anal cancer), oesophageal cancer (C15), gastric cancer (C16), small intestinal cancer $(\mathrm{C} 17)$, colon cancer $(\mathrm{C} 18)$, rectal cancer (C19-20), hepatic cancer (C22), biliary tract cancer (C23: gallbladder, and C24: extrahepatic bile duct cancer) and pancreatic cancer (C25). In addition, stratified analyses were performed by sublocalisation of GI cancer sites (see Supplementary Table 1 for sublocalisations). For the site-specific analyses, subjects were followed until the first-occurrence of the sitespecific GI cancer event, despite other types of GI cancers occurring during follow-up.

\section{4.. Covariables}

Both time-fixed and time-dependent covariables were considered as confounders based on the existing 


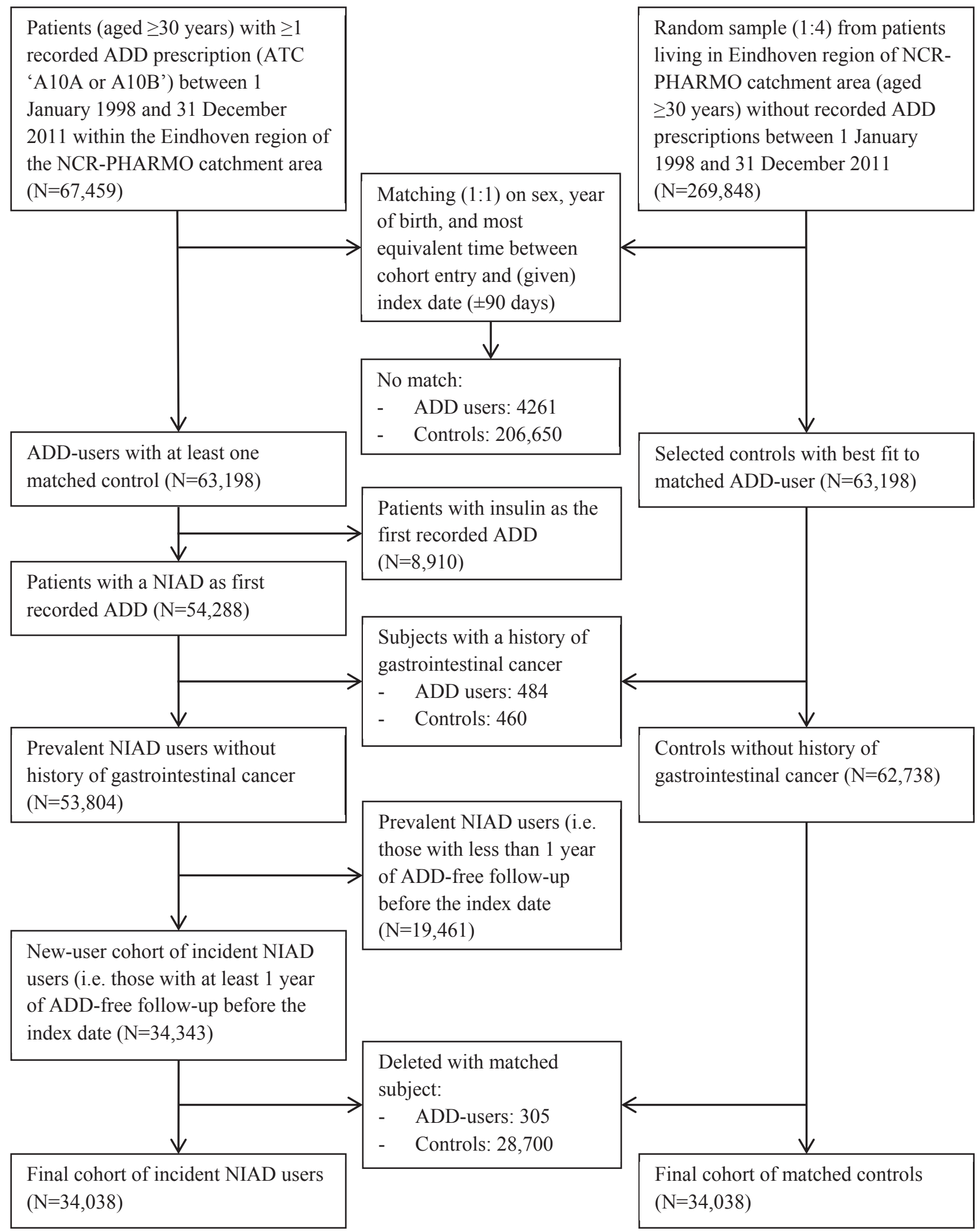

Fig. 1. Flow-chart of study population. Abbreviations: ADD, anti-diabetic drug; ATC, Anatomical Therapeutic Classification; NCR, Netherlands Cancer Registration; NIAD, non-insulin anti-diabetic drug.

literature. As time-fixed covariables sex and the number of hospitalisations before the index date (hospitalisation categories 0 or $\geq 1$ ) were considered. Timedependent covariables were determined at the start of every 90-day time-period and included: age, the duration of diabetes in years (time since first recorded NIAD prescription), the use of other drugs known to impact GI cancer risk in the 90 days before the start of each 
interval (statins, aspirin, non-aspirin non-steroidal antiinflammatory drugs, proton pump inhibitors (PPIs), bisphosphonates, tamoxifen and oral contraceptives). In addition, the use of Helicobacter pylori eradication therapy was used as a proxy-indicator for Helicobacter pylori infection (see Supplementary Table 2 for ATC codes).

\subsection{Statistical analyses}

Differences in demographic and clinical characteristics at baseline between T2DM patients and matched controls were compared using chi-squared test for categorical variables and Student's t-test for continuous variables. Incidence rates (IR) of GI cancer for every (sub)group were calculated by dividing the number of GI cancer events by the total amount of person-years of follow-up (for the IR of GI cancers by tumour stage see Supplementary Table 3).

Cox proportional hazards analysis was used to estimate the hazard ratio (HR) and 95\% confidence intervals (CIs) of GI cancer in T2DM patients versus matched controls. Stratified analyses were performed by sex, for specific GI cancer sites and for subsites of specific GI cancer sites. Covariables were entered into the final model if they changed the beta coefficient of the primary exposure variable by more than $5 \%$. Detection bias after the onset of T2DM was reduced by repeating the overall analyses with a lag-period of 1 year. The lagperiod implied censoring a subject on the date of cancer diagnosis if the cancer occurred during the first year of follow-up.

\subsection{Sensitivity analysis}

To further explore the effects of reducing detection bias, we preformed sensitivity analyses in which we repeated the 1-year lagged analyses as described previously with a lag-period of three years instead. All data management and analyses were performed with SAS software version 9.4 (SAS Institute, Cary, NC).

\section{Results}

\subsection{Baseline characteristics}

In both T2DM patients and non-diabetic controls, the mean age at baseline was 63.9 years, and $51 \%$ of subjects were males (Table 2). There were no differences seen between the age and sex distribution at baseline. After at least 1 year of ADD-free follow-up, most incident ADD users initiated treatment with metformin $(73.8 \%)$ and/or sulfonylureas $(28.0 \%)$. Statistically significant differences were observed for the use of various other drugs during the 90 days before the start of follow-up, with the largest differences seen for prior use of statins, antihypertensives and PPIs. In addition, T2DM patients were more often hospitalised before the index date $(51.7 \%$ versus $38.5 \%)$.

\subsection{Risk of GI cancer overall}

Generally, an increased risk of GI cancer was observed in patients with T2DM compared with non-diabetic controls (Adj. HR 1.5, 95\% CI 1.3-1.7; Table 3),

Table 2

Baseline characteristics of type 2 diabetic patients and matched non-diabetic controls.

\begin{tabular}{|c|c|c|c|c|c|}
\hline \multirow{2}{*}{$\begin{array}{l}\text { Characteristic } \\
\text { Age (years; mean, SD) }\end{array}$} & \multicolumn{2}{|c|}{ Type 2 diabetic $(\mathrm{n}=34,038)$} & \multicolumn{2}{|c|}{ Non-diabetic $(\mathrm{n}=34,038)$} & \multirow{2}{*}{$\frac{\mathrm{p} \text {-value }}{1.00}$} \\
\hline & 63.9 & 12.6 & 63.9 & 12.6 & \\
\hline Sex $(\mathrm{n}, \%$ male $)$ & 17,343 & 51 & 17,343 & 51 & 1.00 \\
\hline \multicolumn{6}{|l|}{ Use of anti-diabetic drugs ${ }^{\mathrm{b}}(\mathrm{n}, \%)$} \\
\hline Metformin & 25,115 & 73.8 & & & \\
\hline Sulfonylureas & 9536 & 28.0 & & & \\
\hline Thiazolidinediones & 388 & 1.1 & & & \\
\hline Meglitinides & 38 & 0.1 & & & \\
\hline Incretins & 66 & 0.2 & & & \\
\hline \multicolumn{6}{|l|}{ Use of other drugs (n, \%) } \\
\hline Anti-hypertensives & 20,667 & 60.7 & 9495 & 27.9 & $<0.01$ \\
\hline Aspirin & 6156 & 18.1 & 3080 & 9.1 & $<0.01$ \\
\hline Bisphosphonates & 1112 & 3.3 & 812 & 2.4 & $<0.01$ \\
\hline H. pylori eradication therapy & 40 & 0.1 & 24 & 0.1 & 0.05 \\
\hline Non-aspirin NSAIDs & 5171 & 15.2 & 3324 & 9.8 & $<0.01$ \\
\hline Proton pump inhibitors & 6795 & 20.0 & 3268 & 9.6 & $<0.01$ \\
\hline Statins & 13,396 & 39.4 & 4529 & 13.3 & $<0.01$ \\
\hline \multicolumn{6}{|l|}{ History of hospitalisations (n, \%) } \\
\hline 0 hospitalisations & 16,450 & 48.3 & 20,932 & 61.5 & $<0.01$ \\
\hline$\geq 1$ hospitalisations & 17,588 & 51.7 & 13,106 & 38.5 & \\
\hline
\end{tabular}

Abbreviations: H. pylori, Helicobacter pylori; NSAIDs, non-steroidal anti-inflammatory drugs.

${ }^{a}$ p-value based on Student's t-test for continuous variables and chi-squared test for categorical variables.

b During 90 days before the index date. 
Table 3

Risk of GI cancer in patients with type 2 diabetes mellitus and matched non-diabetic controls, by specific GI cancer site.

\begin{tabular}{|c|c|c|c|c|c|c|c|c|c|c|c|c|}
\hline \multirow[t]{3}{*}{ Cancer site } & & & & & Age- & ex adjusted & & & Fully & djusted & & \\
\hline & \multicolumn{2}{|c|}{ Non-diabetic } & \multicolumn{2}{|c|}{ Type 2 diabetic } & \multicolumn{2}{|c|}{ Overall } & \multicolumn{2}{|c|}{ One-year lagged } & \multicolumn{2}{|c|}{ Overall } & \multicolumn{2}{|c|}{ One-year lagged } \\
\hline & Events & $\mathrm{IR}^{\mathrm{a}}$ & Events & $\mathrm{IR}^{\mathrm{a}}$ & HR & $95 \% \mathrm{CI}$ & HR & $95 \% \mathrm{CI}$ & $\mathrm{HR}^{\mathrm{b}}$ & $95 \% \mathrm{CI}$ & $\mathrm{HR}^{\mathrm{b}}$ & $95 \% \mathrm{CI}$ \\
\hline \multicolumn{13}{|l|}{ By cancer subsite } \\
\hline Upper GI cancer & 71 & 51 & 96 & 67 & $1.4^{*}$ & $1.0-1.9$ & $1.7^{*}$ & $1.2-2.5$ & 1.1 & $0.77-1.5$ & 1.3 & $0.90-2.0$ \\
\hline Oesophageal cancer & 25 & 18 & 41 & 29 & $1.7^{*}$ & $1.0-2.8$ & $2.3^{*}$ & $1.3-4.1$ & $1.3^{\mathrm{c}}$ & $0.74-2.2$ & $1.6^{\mathrm{c}}$ & $0.86-3.1$ \\
\hline Gastric cancer & 46 & 33 & 50 & 35 & 1.1 & $0.75-1.7$ & 1.4 & $0.86-2.2$ & 0.88 & $0.57-1.4$ & 1.1 & $0.7-1.8$ \\
\hline Small intestinal cancer & $<5$ & 1 & 6 & 4 & 2.9 & $0.58-14.3$ & 1.5 & $0.2-8.7$ & $\mathrm{e}$ & 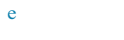 & 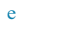 & 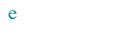 \\
\hline Lower GI cancer & 241 & 173 & 330 & 231 & $1.4^{*}$ & $1.2-1.7$ & $1.4^{*}$ & $1.2-1.7$ & 1.2 & $0.99-1.4$ & 1.1 & $0.93-1.4$ \\
\hline Colon cancer & 168 & 120 & 253 & 176 & $1.6^{*}$ & $1.3-1.9$ & $1.5^{*}$ & $1.2-1.9$ & $1.4^{*}$ & $1.1-1.7$ & 1.2 & $0.96-1.6$ \\
\hline Rectal cancer & 77 & 55 & 87 & 61 & 1.1 & $0.83-1.5$ & 1.2 & $0.88-1.8$ & 0.88 & $0.63-1.2$ & 0.99 & $0.68-1.4$ \\
\hline HPB cancer & 39 & 28 & 156 & 109 & $4.0^{*}$ & $2.8-5.7$ & $4.1^{*}$ & $2.5-6.5$ & $4.4^{*}$ & $3.0-6.4$ & $4.0^{*}$ & $2.4-6.7$ \\
\hline Liver cancer & $<5$ & 1 & 15 & 10 & $7.4^{*}$ & $1.7-32.4$ & - & - & $\mathrm{e}$ & & $\mathrm{e}$ & $\mathrm{e}$ \\
\hline Biliary tract cancer & 7 & 5 & 20 & 14 & $2.9^{*}$ & $1.2-6.7$ & $3.5^{*}$ & $1.2-10.7$ & $3.5^{\mathrm{d}, *}$ & $1.4-8.4$ & $4.2^{\mathrm{d}, *}$ & $1.3-13.1$ \\
\hline Pancreatic cancer & 30 & 21 & 122 & 85 & $4.1^{*}$ & $2.7-6.1$ & $3.5^{*}$ & $2.0-6.0$ & $4.7^{*}$ & $3.1-7.2$ & $3.6^{*}$ & $2.0-6.5$ \\
\hline
\end{tabular}

Abbreviations: CI, confidence interval; GI, gastrointestinal; HPB, hepato-pancreatico-biliary; HR, hazard ratio; IR, incidence rate.

*Statistically significant with $\mathrm{p}<0.05$.

${ }^{\text {a }}$ Per 100,000 person years.

${ }^{\mathrm{b}}$ Adjusted for age, sex, use of statins, proton pump inhibitors, anti-hypertensives 90 days before start of each time-interval.

${ }^{c}$ Additionally adjusted for history of hospitalisation.

d Adjusted only for use of statins 90 days before the start of each interval.

${ }^{\text {e }}$ Fully adjusted analysis not possible due to insufficient events for additional covariate adjustments.

which remained statistically significant increased when applying a 1-year lag-period (Adj. HR 1.4, 95\% CI 1.2-1.7). After stratification by GI cancer subsite, we observed a 4-fold increased risk of hepato-pancreaticobiliary (HPB) cancer (Adj. HR 4.4, 95\% 3.0-6.4), but not for upper and lower GI cancer (Adj. HR 1.1, 95\% CI $0.77-1.5$ and Adj. HR 1.2, 95\% CI 0.99-1.4, respectively). In the analysis that reduced detection bias (i.e. with the addition of a 1-year lag-period), a slightly attenuated risk of HPB cancer was seen (Adj. HR 4.0, 95\% CI 2.4-6.7). When stratifying the analyses by sex, statistically significant increased risks of overall GI cancer and of lower GI cancer were seen in the 1-year lagged analyses in men (Adj. HR 1.6, 95\% CI 1.2-1.9, and Adj. HR 1.3, 95\% CI 1.0-1.8 respectively), but not in women (Table 4). Also, the increased risk of HBP cancer was more pronounced in men than in women.

\subsection{Risk of specific GI cancer sites}

After we had broken down our analyses by GI cancer site, we observed a statistically significant increased risk of colon cancer (Adj. HR 1.4, 95\% CI 1.1-1.7), pancreatic cancer (Adj. HR 4.7, 95\% CI 3.1-7.2) and biliary tract cancer (Adj. HR 3.5, 95\% CI 1.4-8.4) in patients with T2DM compared with non-diabetic controls (Table 3). The latter two remained significantly increased in the 1-year lagged analysis (Adj. HR 3.6, 95\% CI 2.0-6.5 and Adj. HR 4.2, 95\% CI 1.3-13.1, respectively). However, no statistically significantly increased risk of pancreatic or biliary tract cancer was seen in the sensitivity analyses (Adj. HR 2.0, 95\% CI
0.96-4.2 and Adj HR 8.1, 95\% CI 0.95-68.8 respectively). In the sex-specific analyses, the increased risk of colon cancer confined to men, and the risk of pancreatic cancer was more pronounced in men (Table 4).

\subsection{Risk of GI cancer subsites/subtypes}

After stratifying the specific GI cancer sites by sublocalisation and subtype (Table 5), an increased risk in patients with T2DM was found for extrahepatic bile duct cancer (Adj. HR 4.2, 95\% CI 1.5-11.8), and for distal colon cancer (HR 1.5, 95\% 1.1-2.1), both of which remained statistically significantly raised after removal of detection bias. No significant differences were observed for other subsites of GI cancer. Also, we did not observe any significant differences for histologic subtypes of oesophageal cancer.

\section{Discussion}

We observed a $50 \%$ increased risk of GI cancer in patients with T2DM compared with non-diabetic controls. However, after accounting for potential detection bias this dropped to a $40 \%$ increased risk. The overall increased risk in T2DM patients was explained by a four-fold increased risk of HPB cancers, which was driven by pancreatic cancer (five-fold increase) and biliary tract cancer (four-fold increase). The risk of HPB and pancreatic cancer, but not biliary tract cancer, was attenuated following adjustment to minimise detection bias.

While several pathways have been proposed, including insulin resistance and fat-induced chronic 
Table 4

Sex-specific risk of GI cancer in patients with type 2 diabetes mellitus and matched non-diabetic controls, by specific GI cancer site.

\begin{tabular}{|c|c|c|c|c|c|c|c|c|c|c|c|c|}
\hline \multirow[t]{3}{*}{ Cancer site } & \multirow{2}{*}{\multicolumn{2}{|c|}{ Non-diabetic }} & \multirow{2}{*}{\multicolumn{2}{|c|}{ Type 2 diabetic }} & \multicolumn{4}{|c|}{ Age-sex adjusted } & \multicolumn{4}{|c|}{ Fully adjusted } \\
\hline & & & & & \multicolumn{2}{|c|}{ Overall } & \multicolumn{2}{|c|}{ One-year lagged } & \multicolumn{2}{|c|}{ Overall } & \multicolumn{2}{|c|}{ One-year lagged } \\
\hline & Events & $\mathrm{IR}^{\mathrm{a}}$ & Events & $\mathrm{IR}^{\mathrm{a}}$ & HR & $95 \% \mathrm{CI}$ & HR & $95 \% \mathrm{CI}$ & $\mathrm{HR}^{\mathrm{b}}$ & $95 \% \mathrm{CI}$ & $\mathrm{HR}^{\mathrm{b}}$ & $95 \% \mathrm{CI}$ \\
\hline \multicolumn{13}{|l|}{ Men } \\
\hline $\begin{array}{l}\text { Any GI cancer } \\
\text { By cancer site }\end{array}$ & \multicolumn{11}{|c|}{ By cancer site } & $1.2-1.9$ \\
\hline Upper GI cancer & 52 & 73 & 74 & 101 & $1.5^{*}$ & $1.0-2.1$ & $1.9^{*}$ & $1.2-2.9$ & 1.0 & $0.70-1.5$ & 1.4 & $0.85-2.1$ \\
\hline Oesophageal cancer & 18 & 25 & 34 & 46 & $2.0^{*}$ & $1.1-3.5$ & $3.2^{*}$ & $1.6-6.5$ & $1.3^{\mathrm{c}}$ & $0.71-2.4$ & $2.1^{\mathrm{c}}$ & $0.98-4.5$ \\
\hline Gastric cancer & 36 & 50 & 37 & 50 & 1.1 & $0.66-1.7$ & 1.2 & $0.70-2.0$ & 0.77 & $0.47-1.3$ & 0.90 & $0.50-1.6$ \\
\hline Small intestinal cancer & 0 & - & $<5$ & 5 & - & - & - & - & - & - & - & - \\
\hline Lower GI cancer & 131 & 183 & 185 & 253 & $1.5^{*}$ & $1.2-1.8$ & $1.5^{*}$ & $1.2-1.9$ & $1.3^{*}$ & $1.0-1.7$ & $1.3^{*}$ & $1.0-1.8$ \\
\hline Colon cancer & 85 & 119 & 139 & 189 & $1.7^{*}$ & $1.3-2.2$ & $1.6^{*}$ & $1.2-2.2$ & $1.6^{*}$ & $1.2-2.2$ & $1.4^{*}$ & $1.0-2.0$ \\
\hline Rectal cancer & 49 & 68 & 54 & 73 & 1.1 & $0.75-1.6$ & 1.3 & $0.87-2.2$ & 0.91 & $0.59-1.4$ & 1.2 & $0.72-1.9$ \\
\hline HPB cancer & 20 & 28 & 84 & 115 & $4.3^{*}$ & $2.6-6.9$ & $4.5^{*}$ & $2.3-9.0$ & $4.8^{*}$ & $2.9-8.1$ & $4.5^{*}$ & $2.2-9.4$ \\
\hline Liver cancer & 0 & - & 10 & 14 & - & - & - & - & - & - & - & - \\
\hline Biliary tract cancer & $<5$ & 6 & 8 & 11 & $2.1^{*}$ & $0.62-6.9$ & 2.7 & $0.51-13.8$ & 3.0 & $0.86-10.2$ & 4.0 & $0.75-21.4$ \\
\hline Pancreatic cancer & 16 & 22 & 67 & 91 & $4.2^{*}$ & $2.5-7.3$ & $4.2^{*}$ & $2.0-9.1$ & $5.0^{*}$ & $2.8-8.8$ & $4.3^{*}$ & $1.9-9.8$ \\
\hline \multicolumn{13}{|l|}{ Women } \\
\hline Any GI cancer & 148 & 218 & 239 & 343 & $1.6^{*}$ & $1.3-2.0$ & $1.5^{*}$ & $1.2-1.9$ & $1.4^{*}$ & $1.1-1.8$ & 1.2 & $0.92-1.6$ \\
\hline \multicolumn{13}{|l|}{ By cancer site } \\
\hline Upper GI cancer & 19 & 28 & 22 & 32 & 1.2 & $0.64-2.8$ & 1.3 & $0.65-2.6$ & 1.3 & $0.67-2.6$ & 1.3 & $0.61-2.9$ \\
\hline Oesophageal cancer & 7 & 10 & 7 & 10 & 1.0 & $0.35-2.9$ & 0.83 & $0.25-2.7$ & 1.3 & $0.41-4.2$ & 0.80 & $0.21-3.0$ \\
\hline Gastric cancer & 10 & 15 & 13 & 19 & 1.4 & $0.60-3.1$ & 2.1 & $0.79-5.7$ & 1.4 & $0.55-3.4$ & 2.0 & $0.67-5.8$ \\
\hline Small intestinal cancer & $<5$ & 3 & $<5$ & 3 & 0.95 & $0.13-6.8$ & 0.48 & $0.04-5.3$ & 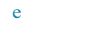 & & 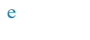 & 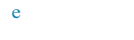 \\
\hline Lower GI cancer & 110 & 162 & 145 & 208 & $1.3^{*}$ & $1.0-1.7$ & 1.3 & $0.94-1.7$ & 1.0 & $0.79-1.4$ & 0.91 & $0.66-1.3$ \\
\hline Colon cancer & 80 & 122 & 114 & 163 & $1.4^{*}$ & $1.1-1.9$ & 1.3 & $0.95-1.9$ & 1.1 & $0.82-1.5$ & 1.0 & $0.70-1.5$ \\
\hline Rectal cancer & 28 & 41 & 33 & 47 & 1.2 & $0.72-2.0$ & 1.1 & $0.62-1.9$ & 0.83 & $0.48-1.5$ & 0.73 & $0.39-1.4$ \\
\hline HPB cancer & 19 & 28 & 72 & 103 & $3.7^{*}$ & $2.3-6.2$ & $3.6^{*}$ & $1.9-7.1$ & $4.0^{*}$ & $2.3-6.9$ & $3.6^{*}$ & $1.8-7.4$ \\
\hline Liver cancer & $<5$ & 3 & 5 & 7 & 2.5 & $0.48-12.7$ & - & - & e & e & e & e \\
\hline Biliary tract cancer & $<5$ & 4 & 12 & 17 & $3.9^{*}$ & $1.1-13.9$ & 4.4 & $0.96-20.6$ & $4.2^{\mathrm{d}, *}$ & $1.1-15.6$ & $4.5^{\mathrm{d}, *}$ & $0.93-22.0$ \\
\hline Pancreatic cancer & 14 & 21 & 55 & 78 & $3.9^{*}$ & $2.2-7.0$ & $2.9^{*}$ & $1.3-6.1$ & $4.5^{*}$ & $2.4-8.3$ & $3.0^{*}$ & $1.3-6.9$ \\
\hline
\end{tabular}

Abbreviations: CI, confidence interval; GI, gastrointestinal; HPB, hepato-pancreatico-biliary; HR, hazard ratio; IR, incidence rate.

*Statistically significant with $\mathrm{p}<0.05$.

${ }^{a}$ Per 100,000 person-years.

b Adjusted for age, use of statins, proton pump inhibitors, anti-hypertensives 90 days prior to start of each time-interval.

c Additionally adjusted for history of hospitalisation.

${ }^{\mathrm{d}}$ Adjusted only for use of statins 90 days prior to start of each interval.

${ }^{\mathrm{e}}$ Fully adjusted analysis not possible due to insufficient events for additional covariate adjustments.

inflammation [5,29], the precise biological mechanisms by which T2DM increases the risk of GI cancer remains unclear. Insulin may promote carcinogenesis through the insulin receptor and insulin-like growth factorreceptor (IGF-R), which are overexpressed on various types of tumour cells [30]. Binding of these receptors by insulin activates the mTOR signalling pathway (mammalian target of rapamycin signalling pathway), resulting in abnormal cell proliferation, inhibition of apoptosis, angiogenesis and carcinogenesis [31]. Hyperinsulinemia may also predispose to carcinogenesis by indirectly increasing the production of IGF-1 via the liver, and by increasing the amount of bioavailable IGF1 by decreasing the level of IGF-binding proteins [29].

The results of this study add to the current evidence from observational studies. In their meta-analyses of cohort studies, Ben et al. [14] found a two-fold increased risk of pancreatic cancer in newly diagnosed T2DM patients, and Ren et al. [13] observed a 1.4-fold increased risk of extrahepatic biliary tract cancer, However, the potential for reverse causality is a primary concern for these cancers, as both can induce hyperglycemia or frank diabetes [32]. Our results may still be affected by an unknown degree of protopathic bias (reverse causality), as a 1-year lag-period may not be enough to exclude the effects of these cancers on the development of T2DM symptoms. Indeed, when increasing the lag-period to 3 years, no statistically significantly increased risks of pancreatic cancer and biliary tract cancer between T2DM patients and controls were observed (Adj. HR 2.0, 95\% CI 0.96-4.8 and Adj. HR 8.1, 95\% CI 0.95-68.8, respectively). However, this could also be explained by a lack of statistical power. Nonetheless, an increased risk of pancreatic cancer with longstanding T2DM ( $\geq 10$ years) has been reported in the literature, suggesting that diabetes might still be a risk factor for pancreatic cancer development [14]. 
Table 5

Risk of GI cancer in patients with type 2 diabetes mellitus and matched non-diabetic controls, by GI cancer subsite.

\begin{tabular}{|c|c|c|c|c|c|c|c|c|c|c|c|c|}
\hline \multirow[t]{3}{*}{ Cancer site } & \multirow{2}{*}{\multicolumn{2}{|c|}{ Non-diabetic }} & \multirow{2}{*}{\multicolumn{2}{|c|}{ Type 2 diabetic }} & \multicolumn{4}{|c|}{ Age-sex adjusted } & \multicolumn{4}{|c|}{ Fully adjusted } \\
\hline & & & & & \multicolumn{2}{|c|}{ Overall } & \multicolumn{2}{|c|}{ One-year lagged } & \multicolumn{2}{|c|}{ Overall } & \multicolumn{2}{|c|}{ One-year lagged } \\
\hline & Events & $\mathrm{IR}^{\mathrm{a}}$ & Events & $\mathrm{IR}^{\mathrm{a}}$ & HR & $95 \% \mathrm{CI}$ & HR & $95 \% \mathrm{CI}$ & $\mathrm{HR}^{\mathrm{b}}$ & $95 \% \mathrm{CI}$ & $\mathrm{HR}^{\mathrm{b}}$ & $95 \% \mathrm{CI}$ \\
\hline \multicolumn{13}{|l|}{ Oesophageal cancer } \\
\hline \multicolumn{13}{|l|}{ By cancer subsite } \\
\hline $\begin{array}{c}\text { Upper/middle } \\
\text { oesophageal cancer }\end{array}$ & $<5$ & 2 & 7 & 5 & 2.3 & $0.59-8.8$ & 1.9 & $0.49-7.8$ & $\mathrm{e}$ & $\mathrm{e}$ & e & e \\
\hline $\begin{array}{l}\text { Lower oesophageal } \\
\text { cancer }\end{array}$ & 21 & 15 & 32 & 22 & 1.6 & $0.92-2.8$ & $2.5^{*}$ & $1.3-5.0$ & $1.2^{\mathrm{c}}$ & $0.68-2.2$ & $1.9^{\mathrm{c}}$ & $0.92-4.0$ \\
\hline \multicolumn{13}{|l|}{ By histologic subtype } \\
\hline $\begin{array}{l}\text { Squamous cell } \\
\text { carcinoma }\end{array}$ & 7 & 5 & 10 & 7 & 1.4 & $0.54-3.7$ & 1.6 & $0.52-4.9$ & e & $\mathrm{e}$ & e & $\mathrm{e}$ \\
\hline Adenocarcinoma & 17 & 12 & 29 & 20 & 1.8 & $0.99-3.3$ & $2.7^{*}$ & $1.3-5.6$ & 1.3 & $0.68-2.4$ & 1.9 & $0.86-4.1$ \\
\hline \multicolumn{13}{|l|}{ Gastric cancer } \\
\hline \multicolumn{13}{|l|}{ By cancer subsite } \\
\hline Proximal gastric cancer & 20 & 14 & 21 & 15 & 1.1 & $0.59-2.0$ & 1.2 & $0.59-2.4$ & 0.89 & $0.46-1.7$ & 0.97 & $0.45-2.1$ \\
\hline Distal gastric cancer & 10 & 7 & 11 & 8 & 1.2 & $0.51-2.9$ & 1.8 & $0.68-4.6$ & e & e & e & $\mathrm{e}$ \\
\hline \multicolumn{13}{|l|}{ Biliary tract cancer } \\
\hline \multicolumn{13}{|l|}{ By cancer subsite } \\
\hline Gallbladder cancer & $<5$ & 1 & $<5$ & 3 & 2.0 & $0.36-10.9$ & 2.0 & $0.18-21.6$ & e & e & e & e \\
\hline $\begin{array}{l}\text { Extrahepatic bile } \\
\text { duct cancer }\end{array}$ & 5 & 4 & 16 & 11 & $3.2^{*}$ & $1.2-8.7$ & $4.1^{*}$ & $1.2-14.4$ & $4.2^{\mathrm{d}, *}$ & $1.5-11.8$ & $5.5^{\mathrm{d}, *}$ & $1.5-20.0$ \\
\hline \multicolumn{13}{|l|}{ Colon cancer } \\
\hline \multicolumn{13}{|l|}{ By cancer subsite } \\
\hline Proximal colon cancer & 90 & 64 & 136 & 95 & $1.6^{*}$ & $1.2-2.0$ & 1.3 & $0.98-1.8$ & 1.3 & $0.98-1.8$ & 1.1 & $0.75-1.5$ \\
\hline Distal colon cancer & 71 & 51 & 112 & 78 & $1.6^{*}$ & $1.2-2.2$ & $1.8^{*}$ & $1.3-2.5$ & $1.5^{*}$ & $1.1-2.0$ & $1.5^{*}$ & $1.1-2.2$ \\
\hline
\end{tabular}

An interesting finding in this study was the difference in risk between genders and distal and proximal colon cancer. We identified that men, but not women, with T2DM were at an increased risk of colon cancer. Varying differences in the risk of colorectal cancer have been reported in men and women with T2DM [25,33-35], and large meta-analyses of observational studies have reported moderate $(20-30 \%)$ increased risks of colorectal cancer in both men and women $[8,16,17,36-38]$. With regards to colon cancer, three meta-analyses have reported increased risks of both proximal and distal colon cancer in patients with T2DM, with stronger risk estimates for proximal colon cancer $[16,37,38]$. However, differences in observed risks could result from variations in the definitions of proximal and distal colon cancer in the literature as it cannot always be defined from which part of the colon a tumour has originated.

In contrast to meta-analyses of cohort studies, we did not find a statistically significant increased risk of liver cancer in patients with T2DM. Wang et al. [15] reported a relative risk of $2.4(95 \%$ CI $1.7-3.6)$ for hepatocellular carcinoma in T2DM patients, combining results from seven cohort studies. The most likely reason we could not replicate these findings is because of a lack of statistical power for this cancer site. Similarly, we did not find an increased risk of specific upper GI cancer sites like oesophageal, gastric, and small intestinal cancer in our cohort. Moreover, when all sites were combined we also did not identify an increased risk of upper GI cancer. This adds to the current literature for the risk of upper GI cancers, such as oesophageal and gastric cancer, in patients with T2DM [6,39-42].

Our study has a number of limitations worth mentioning. First, we were not able to correct for several important general and cancer-specific risk factors, including obesity, smoking status, alcohol use, physical inactivity and high-caloric diet, which could have confounded the results. The majority of T2DM patients are obese, and obesity has been shown to be associated with and increased risk of GI cancers [43]. Moreover, visceral or abdominal fat is more metabolically active and therefore potentially more harmful than fat distributed at the hips [31]. Second, due to the relatively small size of the population and the matched design, a lack of statistical power existed for cancer sites, such as liver cancer and small intestinal cancer. This also resulted in a limited ability to statistically adjust for confounders in a multivariate analysis for 
subsites of GI cancer. Although we acknowledge that propensity score adjustment would be an effective strategy to further reduce residual confounding and limit the number of covariates in the multivariate model [22], it cannot overcome the unmeasured confounding in the data source and therefore this strategy was not applied. Third, the subsite-specific analyses were of an exploratory nature rather than a hypothesis-testing one.

Fourth, T2DM patients were identified based on the use of anti-diabetic drugs, leading to potential misclassification of diet-controlled T2DM patients as controls. Also, included patients were required to have at least one drug prescription via their community pharmacy. Patients not registered at a pharmacy were therefore not included. Consequently, the control group may be sicker than the general population, which may have resulted in an elevated risk of GI cancer in this group. Ultimately, this would bias the risk ratio towards the null, yet we observed a statistically significant association between T2DM and GI cancer sites.

Finally, a causal relationship between T2DM and GI cancer cannot be proven in the present study. T2DM may function as a proxy indicator of several pathophysiologic mechanisms that, in turn, may promote cancer growth, such as insulin resistance, hyperglycemia, hyperinsulinemia, chronic inflammation and increase hormone levels.

The strengths of this study are provided by the use of the population-based linked NCR-PHARMO database, which guarantees a high level of cancer ascertainment and longitudinal information on drug exposure during follow-up. This prevents an overestimation of the number of (false positive) cancers, which may occur in studies using an insurance claims database or data from general practitioners without linking to some form of cancer registry or pathology database. In addition, the longitudinal nature of the PHARMO database provides reliable information on confounding drug exposures during follow-up; such as statins, non-steroidal anti-inflammatory drugs and PPIs.

In conclusion, following an adjustment for potential detection bias, T2DM was associated with a $40 \%$ increased risk of GI cancer, and a four-fold increased risk of pancreatic and biliary tract cancer. In particular, the strong associations found for HPB cancers and pancreatic cancer may be partly caused by an increased detection of these cancers in the first years after the onset of T2DM. Future studies investigating associations between T2DM and GI cancer should therefore always include a sensitivity analysis in which detection bias or reverse causality are kept to a minimum by including one or multiple years of lag-time.

\section{Funding}

This study was not funded.

\section{Conflict of interest statement}

Myrthe van Herk-Sukel is an employee at PHARMO Institute for Drug Outcomes Research, Utrecht, The Netherlands. This independent research institute financially supported studies for government and related health-care authorities and pharmaceutical companies. This study, however, was not supported by a pharmaceutical company. There were no other conflicts of interest to declare.

\section{Acknowledgements}

Guarantor of the article: R.G.P.J. de Jong.

Specific author contributions: RJ contributed to the formulation of the study design, data analysis, interpretation of the results and wrote the manuscript. AB, AM, $\mathrm{MJ}$ and FV contributed to the formulation of the study design, interpretation of the results and critical revision of the manuscript. SK and HH contributed to the interpretation of the results and critical revision of the manuscript. PJ, MH-S and PV provided the research data and contributed to the critical revision of the manuscript.

All authors have approved the final version of the manuscript.

\section{Appendix A. Supplementary data}

Supplementary data related to this article can be found at http://dx.doi.org/10.1016/j.ejca.2017.03.039.

\section{References}

[1] Netherlands Cancer Registry. Cijfers over kanker: Netherlands Comprehensive Cancer Organization; 2016 [cited 2016 01-092016]. Available from: www.cijfersoverkanker.nl.

[2] De Marco MF, Janssen-Heijnen ML, van der Heijden LH, Coebergh JW. Comorbidity and colorectal cancer according to subsite and stage: a population-based study. Eur J Cancer 2000 Jan;36(1):95-9. PubMed PMID: 10741301.

[3] van de Poll-Franse LV, Houterman S, Janssen-Heijnen ML, Dercksen MW, Coebergh JW, Haak HR. Less aggressive treatment and worse overall survival in cancer patients with diabetes: a large population based analysis. Int J Cancer J Int du Cancer 2007 May 1;120(9):1986-92. PubMed PMID: 17230509.

[4] Peeters PJ, Bazelier MT, Leufkens HG, de Vries F, De Bruin ML. The risk of colorectal cancer in patients with type 2 diabetes: associations with treatment stage and obesity. Diabetes Care 2015 Mar;38(3):495-502. PubMed PMID: 25552419.

[5] Giovannucci E, Harlan DM, Archer MC, Bergenstal RM, Gapstur SM, Habel LA, et al. Diabetes and cancer: a consensus report. CA Cancer J Clin 2010 Jul-Aug;60(4):207-21. PubMed PMID: 20554718.

[6] Tsilidis KK, Kasimis JC, Lopez DS, Ntzani EE, Ioannidis JP. Type 2 diabetes and cancer: umbrella review of meta-analyses of observational studies. BMJ 2015;350:g7607. PubMed PMID: 25555821.

[7] Habib SL, Rojna M. Diabetes and risk of cancer. ISRN Oncol 2013;2013:583786. PubMed PMID: 23476808. Pubmed Central PMCID: 3582053. 
[8] Wu L, Yu C, Jiang H, Tang J, Huang HL, Gao J, et al. Diabetes mellitus and the occurrence of colorectal cancer: an updated metaanalysis of cohort studies. Diabetes Technol Ther 2013 May; 15(5):419-27. PubMed PMID: 23540566.

[9] Huang W, Ren H, Ben Q, Cai Q, Zhu W, Li Z. Risk of esophageal cancer in diabetes mellitus: a meta-analysis of observational studies. Cancer Causes Control CCC 2012 Feb;23(2):263-72. PubMed PMID: 22094992.

[10] Ge Z, Ben Q, Qian J, Wang Y, Li Y. Diabetes mellitus and risk of gastric cancer: a systematic review and meta-analysis of observational studies. Eur J Gastroenterol Hepatol 2011 Nov;23(12): 1127-35. PubMed PMID: 21934509.

[11] Jing W, Jin G, Zhou X, Zhou Y, Zhang Y, Shao C, et al. Diabetes mellitus and increased risk of cholangiocarcinoma: a meta-analysis. Eur J Cancer Prev the Official Journal of the European Cancer Prevention Organisation 2012 Jan;21(1):24-31. PubMed PMID: 21857525.

[12] Jiang Y, Ben Q, Shen H, Lu W, Zhang Y, Zhu J. Diabetes mellitus and incidence and mortality of colorectal cancer: a systematic review and meta-analysis of cohort studies. Eur J Epidemiol 2011 Nov;26(11):863-76. PubMed PMID: 21938478.

[13] Ren HB, Yu T, Liu C, Li YQ. Diabetes mellitus and increased risk of biliary tract cancer: systematic review and meta-analysis. Cancer Causes Control CCC 2011 Jun;22(6):837-47. PubMed PMID: 21424210.

[14] Ben Q, Xu M, Ning X, Liu J, Hong S, Huang W, et al. Diabetes mellitus and risk of pancreatic cancer: a meta-analysis of cohort studies. Eur J Cancer 2011 Sep;47(13):1928-37. PubMed PMID: 21458985.

[15] Wang C, Wang X, Gong G, Ben Q, Qiu W, Chen Y, et al. Increased risk of hepatocellular carcinoma in patients with diabetes mellitus: a systematic review and meta-analysis of cohort studies. Int J Cancer J Int du Cancer 2012 Apr 1;130(7):1639-48. PubMed PMID: 21544812.

[16] Larsson SC, Orsini N, Wolk A. Diabetes mellitus and risk of colorectal cancer: a meta-analysis. J Natl Cancer Inst 2005 Nov 16;97(22):1679-87. PubMed PMID: 16288121.

[17] Deng L, Gui Z, Zhao L, Wang J, Shen L. Diabetes mellitus and the incidence of colorectal cancer: an updated systematic review and meta-analysis. Dig Dis Sci 2012 Jun;57(6):1576-85. PubMed PMID: 22350783.

[18] He J, Stram DO, Kolonel LN, Henderson BE, Le Marchand L, Haiman CA. The association of diabetes with colorectal cancer risk: the Multiethnic Cohort. Br J Cancer 2010 Jun 29;103(1): 120-6. PubMed PMID: 20531412. Pubmed Central PMCID: 2905298

[19] Baan CA, Poos MJJC, Uiters E, Savelkoul M. Hoe vaak komt diabetes mellitus voor en hoeveel mensen sterven eraan? Volksgezondheid Toekomst Verkenning. Nationaal Kompas Volksgezondheid Bilthoven; 2014.

[20] Harding JL, Shaw JE, Peeters A, Cartensen B, Magliano DJ. Cancer risk among people with type 1 and type 2 diabetes: disentangling true associations, detection bias, and reverse causation. Diabetes Care 2015 Feb;38(2):264-70. PubMed PMID: 25488912.

[21] De Bruijn KM, Ruiter R, de Keyser CE, Hofman A, Stricker BH, van Eijck $\mathrm{CH}$. Detection bias may be the main cause of increased cancer incidence among diabetics: results from the Rotterdam Study. Eur J Cancer 2014 Sep;50(14):2449-55. PubMed PMID: 25047425.

[22] Patorno E, Garry EM, Patrick AR, Schneeweiss S, Gillet VG, Zorina $\mathrm{O}$, et al. Addressing limitations in observational studies of the association between glucose-lowering medications and allcause mortality: a review. Drug Saf 2015 Mar;38(3):295-310. PubMed PMID: 25761856.

[23] Steevens J, Schouten LJ, Goldbohm RA, van den Brandt PA. Alcohol consumption, cigarette smoking and risk of subtypes of oesophageal and gastric cancer: a prospective cohort study. Gut 2010 Jan;59(1):39-48. PubMed PMID: 19828467.

[24] van Blankenstein M, Looman CW, Hop WC, Bytzer P. The incidence of adenocarcinoma and squamous cell carcinoma of the esophagus: Barrett's esophagus makes a difference. Am J Gastroenterol 2005 Apr;100(4):766-74. PubMed PMID: 15784017.

[25] de Kort S, Simons CC, van den Brandt PA, Goldbohm RA, Arts IC, de Bruine AP, et al. Diabetes mellitus type 2 and subsitespecific colorectal cancer risk in men and women: results from the Netherlands Cohort Study on diet and cancer. Eur J Gastroenterol Hepatol 2016 Aug;28(8):896-903. PubMed PMID: 27097356.

[26] van Herk-Sukel MP, van de Poll-Franse LV, Lemmens VE, Vreugdenhil G, Pruijt JF, Coebergh JW, et al. New opportunities for drug outcomes research in cancer patients: the linkage of the Eindhoven Cancer Registry and the PHARMO Record Linkage System. Eur J Cancer 2010 Jan;46(2):395-404. PubMed PMID: 19811904.

[27] World Health Organization. Collaborating centre for drug stastistics methodology - ATC/DDD index. 2016.

[28] International classification of diseases of Oncology. Version 2013. 1st ed. Geneva: WHO; 1976.

[29] Wojciechowska J, Krajewski W, Bolanowski M, Krecicki T, Zatonski T. Diabetes and cancer: a review of current knowledge. Exp Clin Endocrinol Diabetes Official Journal, German Society of Endocrinology [and] German Diabetes Association 2016 May; 124(5):263-75. PubMed PMID: 27219686.

[30] Belfiore A. The role of insulin receptor isoforms and hybrid insulin/IGF-I receptors in human cancer. Curr Pharm Des 2007; 13(7):671-86. PubMed PMID: 17346183.

[31] Vigneri P, Frasca F, Sciacca L, Pandini G, Vigneri R. Diabetes and cancer. Endocrine-related cancer 2009 Dec;16(4):1103-23. PubMed PMID: 19620249.

[32] Li J, Cao G, Ma Q, Liu H, Li W, Han L. The bidirectional interaction between pancreatic cancer and diabetes. World J Surg Oncol 2012;10:171. PubMed PMID: 22920886. Pubmed Central PMCID: PMC3499274.

[33] Woo H, Lee J, Lee J, Park JW, Park S, Kim J, et al. Diabetes mellitus and site-specific colorectal cancer risk in Korea: a casecontrol study. J Prev Med Public Health 2016 Jan;49(1):45-52. PubMed PMID: 26841884. Pubmed Central PMCID: PMC4750510.

[34] Tavani A, Bravi F, Bosetti C, Franceschi S, Levi F, Talamini R, et al. Diabetes mellitus and subsite-specific colorectal cancer risks in the Iowa Women's Health Study. Cancer Epidemiol Biomarkers Prev a publication of the American Association for Cancer Research, cosponsored by the American Society of Preventive Oncology 2005 Sep;14(9):2277. PubMed PMID: 16172246.

[35] Jarvandi S, Davidson NO, Schootman M. Increased risk of colorectal cancer in type 2 diabetes is independent of diet quality. PLoS One 2013;8(9):e74616. PubMed PMID: 24069323. Pubmed Central PMCID: PMC3771921.

[36] Kramer HU, Schottker B, Raum E, Brenner H. Type 2 diabetes mellitus and colorectal cancer: meta-analysis on sex-specific differences. Eur J Cancer 2012 Jun;48(9):1269-82. PubMed PMID: 21889332.

[37] Luo W, Cao Y, Liao C, Gao F. Diabetes mellitus and the incidence and mortality of colorectal cancer: a meta-analysis of 24 cohort studies. Colorectal Dis 2012 Nov;14(11):1307-12. PubMed PMID: 23046351.

[38] Sun L, Yu S. Diabetes mellitus is an independent risk factor for colorectal cancer. Dig Dis Sci 2012 Jun;57(6):1586-97. PubMed PMID: 22302244.

[39] Dixon JL, Copeland LA, Zeber JE, MacCarthy AA, Reznik SI, Smythe WR, et al. Association between diabetes and esophageal cancer, independent of obesity, in the United States Veterans Affairs population. Dis Esophagus 2016 Oct;29(7):747-51. 
[40] Cheng KC, Chen YL, Lai SW, Tsai PY, Sung FC. Risk of esophagus cancer in diabetes mellitus: a population-based casecontrol study in Taiwan. BMC Gastroenterol 2012;12:177. PubMed PMID: 23234272. Pubmed Central PMCID: 3531311.

[41] Jiang X, Bernstein L, Tseng CC, Wu AH. Diabetes and risk of esophageal and gastric adenocarcinomas. Int $\mathbf{J}$ Cancer $\mathbf{J}$ Int du Cancer 2012 Sep 15;131(6):1417-22. PubMed PMID: 22161620. Pubmed Central PMCID: 3340473.
[42] Tseng CH, Tseng FH. Diabetes and gastric cancer: the potential links. World J Gastroenterol WJG 2014 Feb 21;20(7):1701-11. PubMed PMID: 24587649. Pubmed Central PMCID: 3930970.

[43] Bhaskaran K, Douglas I, Forbes H, dos-Santos-Silva I, Leon DA, Smeeth L. Body-mass index and risk of 22 specific cancers: a population-based cohort study of 5.24 million UK adults. Lancet 2014 Aug 30;384(9945):755-65. PubMed PMID: 25129328. Pubmed Central PMCID: 4151483. 